\title{
Co-Movement of Pakistan Stock Market with the Stock Markets of Major Developed Countries Which Have Portfolio Investment in Pakistan
}

\author{
Muhammad Amir Alvi \\ Government College University Faisalabad, Layyah Campus (Pakistan) \\ Sajjad Hussain Chughtai \\ Government College University Faisalabad, Layyah Campus (Pakistan)
}

\begin{abstract}
The focal objective of this study is to analyze and explore the Co-movement of Pakistan stock market (KSE-100) with the stock market of developed countries (US, UK, Canada, Australia, Germany, Japan, France and Neither land) which have portfolio investment in Pakistan by applying co-integration approach using Johansen and Juselius multivariate and bi-variate co-integration. Secondary data of stock indices of these equity markets covering the period from $1^{\text {st }}$ July 2007 to June 2014 has been used. Analysis of study reveals that Pakistan stock market (KSE-100) is not co moved with any stock market of selected major developed countries. Non-existence of co-movement of KSE offers the investors and fund managers to get the diversification benefits by portfolio investment in KSE. This study will help the investors in searching such markets which have greater diversification benefits because diversification minimizes the risk element. Investors and policy makers can make efficient portfolio investment decisions by studying these analyses. This Study provides awareness and guideline to decision makers including local and foreign investors, agencies, financial analysts and banks about diversification opportunities in equity market of Pakistan.
\end{abstract}

Keywords: Stock markets, stock indices, diversification, Portfolio Investment, globalization.

\section{Introduction}

The core objective of developing economies like Pakistan is to achieve economic growth and development. Besides so many other factors, Investment plays a pivotal role in achieving the economic growth and development of a country. Savings generate investment. Modern Economist Lord J. Keynes (1936) said, Savings are always equal to investment. The best place to utilize the investment is capital market. The function of capital markets is to drive the savings in an effective and efficient way towards the investment portfolios and thus helps to develop an investment culture in the country. Capital market is divided into primary market and secondary market. Secondary market generally known as stock market or equity market is the soundly operated market that provides the facility for buying and selling of already issued long term financial instruments. The key players of this market are companies issuing securities, intermediaries and investors. Co movement of stock market refers to the tendency of similar or parallel movement of two or more markets.

The general objective of investment is to spend the money during the specific time period in order to increase the investor's wealth. An investment decision is based upon the analysis. The specific objective of investment is to make sure the safety of principal amount and to receive the reasonable return on reasonable risk. Investment can be divided into two types: Direct investment and indirect investment. Direct investing can be made by using financial markets while indirect investing includes financial intermediaries. Generally, indirect investing is much correlated with the financial institutions.

At international level, Investors can invest their funds in a country by Foreign Direct Investment (FDI) and by Foreign Portfolio investment (FPI). A portfolio investment is such type of investment in securities in which investor do not has active involvement in the management of the securities. It is a passive investment in its nature and the sole objective of this type of investment is to seek financial gain. Financial institutions are primarily concerned in the business of investing in and managing a portfolio of securities (various types of investment funds or investment companies, private pension funds etc.). Portfolio diversification is concerned with having equities in various markets, for example holding equity in Asian, European and American markets.

The object of diversification is to minimize the risk and maximize the return. Williams (1938) said, "All risk could be removed by holding a portfolio with a wide variety of financial assets, which proved to be a false statement". According to Portfolio diversification model by Harry Markowitz (1952), investors can minimize risk by keeping a diversified portfolio investment in different or same equity market. Co movement of stock markets limits the benefits of portfolio diversification for foreign investors in the long run. Internationalization provides an opportunity to local and foreign investors to extend their portfolio for reasonable return. It is necessary for the investors and portfolio managers to have information about the arrangement of international financial markets. It is also necessary for investors and portfolio managers to know that this diversification will 
grant profit or loss.

In order to enjoy the benefits of diversification, investors are searching such global markets which can provide them diversification opportunities with maximum return on minimum risk. Higher returns and lower risk of foreign strong equity markets has attracted the foreign investors to invest their funds in the capital market of developed countries. Many other factors like political instability, poor law and order situation, energy crises, terrorism and no protection to life in native countries moved the local investors to shift their capital in the equity markets of strong economic foreign countries. On the other side, less economic barriers, relaxed policies and market opportunities of developing countries attracted the foreign investors as emerging economies need foreign capital inflow for the development of economy.

Movement of capital from one country to another country is the cause of linkage among the globe stock markets. Global financial crisis like Asian financial crisis in 1997 and crisis on wall-street (global stock market crash) in 1987 was the major cause of increase in linkage among the markets of the world. WTO, Economic integration, Economic block and regionalization have also increased the stock market integration. In mid-1997, East Asian financial crisis proved to be a global financial and economic disaster, prominent emerging countries and globe stock exchanges responded to the breakdown of the New York Stock Exchange. There were extreme Economic crisis in US at the end of 2007 known as World economic crisis. The main cause of 2007 world crisis was the loose of investor's confidence in mortgage securities which resulted in liquidity crisis and the crisis spread all over the world. Financial crisis and economic integration have developed an increasing interest of the researchers to examine the co-movement of stock markets because these collapses were quickly spread throughout the globe equity markets.

The increasing integration of the world economy has increased the integration and effectiveness of individual stock markets. World Bank Report 1997 describes that globe stock markets are quickly converting into a single global market and financiers are searching such emerging markets for higher profits and to explore new prospects for risk divergence because the industrial and financial arrangement of emerging economies are in evolving stage. Bekaert and Harvey (1995) explained that a market is affected by the commercial and financial strategies implemented by its state or monitoring institution, whether this market is integrated with the global stock markets or segmented.

The financial economics theory proposes that financial development and stability is influenced by strong financial integration. The theory also arguments that financial integration increases the efficient allocation of capital, reduces the possibility of shocks, more strong market structure and higher portfolio diversification. (Paurer 2005). For financial economic theory and practical asset management, it is necessary to know about the co-movements of stock markets. According to Efficient market hypothesis; new market informations are well responded by capital market. As regards finance theory if the Efficient Market Hypothesis (EMH) grips in any of its types then equity prices should not be likely using freely obtainable data like equity prices of other stock markets. This excludes any modification over time between two equity markets. However if there is a comovement among the equity markets, the EMH is debased because one market comprises monetary data about the other which aids to forecast its future.

Globalization, liberalization and technological advancement are the main cause of recent integration of local and foreign financial markets. Globalization plays an important role in increasing the co-movements among the equity markets. According to Bekaert and Harvey (1997) financial market liberalization did increase the linking among the returns of diverse equity markets. Most of the Policy makers claimed that financial integration presented numerous benefits like economic development and growth, greater investment, increased financial intermediation process and improve competition environment. Investor's access has been increased to globe equity markets which proposes healthier opportunity for portfolio diversification and looking for higher risk adjusted profits.

\subsection{OBJECTIVES OF THE STUDY}

Following are the objectives of the study in order to:

- $\quad$ Find out the co-movement of Pakistani stock market with the stock markets of major developed countries;

- Explore the existence of diversification opportunities for portfolio investment in the stock market of Pakistan (KSE-100).

\subsection{SIGNIFICANCE OFTHE STUDY}

Equity markets play a vital role for the provision and movement of funds for economic development and growth from investors to borrowers. Generally speaking stock markets are likely to accelerate economic growth by liquidating financial assets and diversifying the global risk easier for investors for making sensible investment decisions. Uncertainty in the market due to any reason makes the investors to evade investing in the stock markets. In order to examine whether there is a significant empirical relationship between stock markets, 
this study provides the alternative investment opportunities to the investors to make the portfolio of their investments and enjoying the benefits of diversification. Investors anticipate higher rate of returns by differentiating their investments across the world but co movement of stock markets will reduce the rate of returns for international portfolio. So the study of co-movements of such stock markets having portfolio investment in Pakistan is significant in global portfolio perspective.

\section{Literature Review}

Co-integration analyses are commonly used to ascertain the co movement among the stock markets and the study of co-integration has remained a field of interest for the investors, fund managers, financial analysts and economists.

Shah, Husnain and Ali (2012) conducted a study to examine the relationship of Pakistan stock market (KSE-100 index) with Great Eight Countries named G-8 group which includes US, UK, Canada, Germany, Japan, France, Italy and Russia by applying Co-integration approach using Johnson and Julius, VECM, Granger Causality test, Impulse response test and Variance decomposition test on 5 years weekly returns data and respective exchange markets extended from June 2004 to May 2009. The result evidenced that there was no long run relation of Pakistan stock market with G-8 country's stock markets. They suggested that the investors and fund managers of USA, Canada, Russia and Italy can avail the benefits of portfolio diversification by investing in the Pakistan equity market.

Co-integration is the commonly used approach for the investigation of integration among the stock markets. This approach was firstly used by Kasa (1992) to estimate the similar stochastic trends among the equity markets of developed countries. Fonseca (2013) used this approach in his study to check the stock markets integration of East Europe and Middle East countries and he concluded that there exists these markets are co-integrated. These countries selected for analysis were developed countries including Hungry, Czech, Poland, Russia, Croatia, Solvenia, Estonia, Lithuania, Romania, Serbia and Ukraine and two Middle East countries Turkey and Kazakhstan. The period taken for analysis was extended four years starting from January 2007 to December 2010.He used daily stock indices containing 1045 observations for analysis. The result evidenced that there was co-integration among ten markets out of the fourteen international financial markets and also showed increase in international Portfolio diversification. The analysis also showed that frontier markets are offering new and better investment opportunities for the foreign investors.

Stock market news announcement plays an important role in integration of marks. Market news of US market is the issue of interest for investors. In this context, Many investigations have been made on the interlink age and interdependence effect among the countries after the Economic crisis in US at the end of 2007. These crisis created economic instability and weekend the economies. Morales and Callaghan (2012) conducted a study after the World crisis 2007 in which they investigated the Contagious effects of US stock market on Asian markets. The analysis include daily stock market returns movement for the period from 2003 to 2009 divided into two sub-samples of US and major Asian developed and developing countries. They found that there was comovement between US stock market and Asian markets but US market did not have any contagion effect on Asian markets. They concluded that spread of crisis in rest of the countries was because of higher markets integration or co-movement. It was also observed that markets are the facilitator of crisis or shocks but not the cause of shocks. US market did not have contagion effect on these economies but US market was highly comovement, having strong effect on these countries so crisis spread in these countries.

Horvath and Petrovski (2013) checked co movement between developed global stock markets and Western Europe Central countries and South Eastern Europe countries. Comparative Study was made on two groups containing three countries in each group and their co-integration was analyzed. Countries of each group were Czech Republic, Hungary and Poland (Central Western Europe) and Croatia, Macedonia and Serbia (South Eastern Europe). They used multivariate GARCH approach on the daily stock returns for the period 2006-2011. They found that there was highly co movement of Central European countries with developed countries like US and Canada while South Eastern European countries were not correlated with world stock markets. Effect of Global Stock market crisis on these six countries was also analyzed in the study. Results evidenced that stock markets of Central Eastern were greater co-moved with Western European markets.

Claus and Lucey (2011) Contributed by investigating the equity market integration among the Asian Pacific region by applying latest and different method developed by Flood and Rose (2005) that is concerned with estimation of expected discounts rates. They selected ten countries of the region which includes developed and emerging markets named Australia, Hong Kong, India, Japan, South Korea, Malaysia, New Zealand, Singapore, Taiwan and Thailand. They selected pre-crisis period daily data of 2006 in order to analyze the integration in normal period of time rather than contagion which shows integration in during the crisis period. They concluded that there was higher co movement for Japan, Hong Kong and New Zealand. The results of the study suggested that there was existence of segmentation within the stock markets of Asia Pacific region but with varied degree of segmentation. The results also showed that there was lack of integration in the region of 
Australia, Singapore and New Zealand. They also suggested Liberalization policy for market integration but it is not a sufficient condition.

Esqueda, Assefa and Mollick (2011) explored the influence of stock market volatility on the financial market integration on the hypothesis that more integration leads to lower stock volatility. They used time period from 1997 to 2005 by collecting annual economic data. They also used monthly returns of the stock markets to calculate risk measures. They used panel data and applied Unit root test and GARCH test for the analysis. They concluded that increase in co movement have no impact on stock volatility of the developed countries because developed markets did not give response to globalization. In case of emerging markets, the results showing negative effects of beta-volatility. Their findings suggested that more linkage of equity markets leads to lower stock volatility.

Subhani, Hasan, Mehar and Osman (2011) conducted a study in Pakistan to analyze the co movement among the stock markets of south Asia region. The daily data of stock indices of four countries Pakistan (KSE), India (BSE), Nepal (NSE) and Bangladesh (DSE) for the period May 1995 to May 2011 was examined by applying Co integration approach. They found that KSE was co-moved only with DSE. They checked the cointegration among selected markets by applying unit root test and ADF test and Johanson co-integration test for verification of co-integration. Their finding showed that these markets are co-integrated but there was no evidence of co-movements among these markets with one another except of KSE-Pakistan with BSE-Bangladesh. There was long run linkage of Pakistan stock market with Bangladesh stock market.

Bhunia (2012) attempted to find Co movement between Indian equity market and South Asian countries and also investigated the proficiency of Indian market with respect to other leading south Asian markets. Secondary data containing daily stock prices of 2252 observations from august 2002 to august 2011 were used and Co integration and Granger causality tests were applied for short and long run analysis. Their analysis results evidenced short and long term relationships and diversification opportunities for investors in the short run. Long term linkage was analyzed by using Johanson co integration method and maximum Eigen value test. They suggested that more opportunities for investors to receive the diversification benefits and gains in Indian as well as in leading South Asian markets.

Singh and Singh (2011) made a study on co movement and investigated the relationship of developing and developed markets. Co integration among major developing markets of China and India were examined with the developed markets of United Kingdom, Japan United States, Japan and Hong Kong. Daily data of intra-day stock indices containing 1872 observations extended from January 2000 to December 2009 were used by applying correlation analysis, Granger causality test and co-integration test using Error correction model. Their analysis concluded that Chinese and Indian markets were correlated with all selected developed markets and has unilateral causality effects. Increasing interdependence has increased co movement between stock market of china and India. Correlation results suggest short term co movement with other markets which suggests limited diversification benefits between them.

Petrov (2011) explored the co integration between South African and major developed markets. EngleGranger and Johansen tests were applied to find level of co integration between South African and developed markets of the globe. Weekly data containing stock indices were used for the analysis. The results showed that SA market was co integrated with other globe markets but not with African markets. This study recommended that investors should consider most favorable market portfolio as co integration reduces the benefits of diversifications.

Darrat, Colthup, Li and Zhong (2012) investigated the relationship of markets of Pacific-Basin Region within the regional markets and with outside the region markets like USA and Japan and also check the responsiveness of these markets towards key global incidents. Weekly observations of stock returns covering 21 years extended from January $5^{\text {th }} 1988$ to December $30^{\text {th }} 2008$ have been used for the analysis. Their study covered long run relationship, time variation in the relationship, identification of factors of creating linkage and effect of 9/11 incident. This study includes the indexes of national stock markets of PB region like Australia, Hong Kong, Indonesia, Japan, Malaysia, New Zealand, Philippines), Singapore, Taiwan and Thailand. Co integration and Granger causality test were used and results evidenced co integration and interdependence among the markets within the region. As for US and Japan markets, there was linkage with US market rather than Japan and 9/11 incident has weekend this relation and this factor produces diversification benefits for US investors in the markets of $\mathrm{PB}$ region.

Hoque (2007) inquired the co-movement of stock returns of Bangladesh stock market with other markets like USA, Japan and India. Short and long run linkage has been examined. Daily data of share price index divided into two sub-periods starting from $1^{\text {st }}$ January 1996 to December 2000 has been used for the analysis. Co-integration test, impulse response analysis and VECM approach was used to check the relationship and co-movement and it was found that in the period of global crisis(1987) there was increase in linkage among the markets. They conclude that there was co-integration and common trend between the Bangladesh stock market and other selected markets. 
Kim (2010) explored the co-movement between US stock market and East Asian stock markets including Hong Kong, Singapore, Korea and Taiwan. He made his analysis by taking different time scales by using wavelet analysis (Decomposition of time series data into various time scales). Time period taken were precrisis (1994-1997) period of East Asian financial crisis 1997-2000, during the crisis(1997-2000), inter crisis(2000-2007) and post crisis periods 2007-2009 to check the variation of impact of US market on all markets. Daily data containing the stock Indices were used for the entire markets. Co-integration approach using Granger Causality test and impulse response test were applied. The results proved that US market have causal effects on all markets of East Asian in all periods. The degree of response of these markets to the US market varied between the inter-crisis and mortgage crisis.

Ali, Butt and Rehman (2011) analyzed the co movement of Pakistan stock market with the emerging and developed markets. The selected developing and developed markets were India, China, Indonesia, Singapore, Taiwan, Malaysia, Japan, USA and UK and using co integration approach applying Unit root, Granger Causality, Phillips Perron test and ADF test by taking the monthly stock returns for the period of 10 years extended from 1998 to 2008. The results of the study showed that Pakistan stock market was not co moved with the market of UK, USA, Taiwan, Malaysia and Singapore and suggested that investors can minimize the risk through investing in these markets. The analysis with other markets revealed co movement of Pakistan stock market with India, China, Japan and Indonesia so there is no chance of risk minimization for investment in these countries.

Chen (2011) studied the co movement among the countries and explained the impacts of cross country differences on stock return co movement. Sample of 38 countries for the period extended from 1992 to 2007 were used. Return decomposition and vector auto regressive regression have been used. They found the return co movement for the cash flow news and discount rate co movement of selected countries. To explain the cross country differences discount rate co movement is more important than the cash flow co movement. The results confirmed that cross country differences creates stock return co movement. The findings of the study suggested that in order to understand the cross country differences in within the stock return co movement forces that remove the stock prices from firm's fundamentals are important than the reasons linked to firms' fundamentals.

Chow, Huang and Niu (2013) analyzed the co movement among the East Asian countries with one another and with US. Weekly stock returns for the period of three decades from July 1980 to December 2011 have been taken for the analysis except for China because Shanghai stock market was established in December 1990. Time varying correlation and regression analysis were applied. Countries selected were divided into two categories, First, Newly Industrial Economies (NIEs) including Korea, Hong Kong, Taiwan and Singapore and Second, large economies like Japan, US and China. Relationships between these two categories were observed. The results showed econometric evidence and increasing interdependence within East Asian Economies. Results also showed that there was no close relationship between Japan and US markets. Increasing linkage between China and US was also observed. They suggested constructing econometric models using time varying analysis.

Blackburn and Chidambaran (2013) examined the co movement and change in co movement of 23 developed and 10 emerging countries by taking a period of 30 years from 1980 to 2010 on weekly returns. Weighted Generalized Canonical Correlation (W-GCC) method and W-FF factor model have been applied for these analyses. The results concluded that co movement has increased in the mid of the sample period i.e. 19802010 in both group of countries. They found no difference in stock price co movement of large and small economies. They finally concluded that there was changing in co movement and increased integration in global markets. They suggested that industry and country factors were less relevant for stock returns co movement. Furthermore, their findings have significant importance for those investors looking to diversify internationally.

Hussain and Muhammad (2011) investigated the association of Pakistani equity market with the global emerging equity markets namely UK, India, Germany and China. Weekly data from 2000 to 2010 were taken and Unit root test, Johansen (1988, 1991) and Johansen Juselius (1990) technique and impulse response test were applied. The results showed that Pakistani stock market was highly linked with the US Stock market and US market were creating much volatility as compared to other markets. The results also showed that KSE was not commoved with the markets of US and UK. Risk and return of KSE is at higher level i.e. .41\% as compared to American and European markets. He suggested that KSE is a good and efficient market for foreign investors to diversify their portfolio and took advantage from KSE.

\section{Data Description and methodology}

Monthly closing stock returns of stock markets indices of Pakistan (KSE-100 index) and developed countries has been used for the analysis and data is obtained from yahoo finance for the period extended from July 2007 to June 2014.

In this study, Co-movement of Pakistan stock market has been investigated by using co- integration approach. This study focuses Co-movement of Pakistan stock market with major developed markets. The specific developed countries selected for analysis are USA, UK, Canada, Australia, Germany, Japan, France and Netherland. To include in the analysis, the selection of these eight major developed countries is based on the 
portfolio investment by these countries in Pakistani market.

In order to examine the Co-Movement of Pakistan stock market with selected major developed countries, we will apply the following tests:

- Descriptive Statistics

- Correlation Matrix

- Unit root Tests

- Augmented Dickey Fuller Test

- Phillips-Perron Test

- Vector Auto Regression (VAR) Test

- Johansen and Juselius Co integration Tests

- Multivariate test

- Bivariate test

This study covers co-movement among the stock markets and provide good base for investment decisions. Investors from developed countries can get the benefit of diversification by investing in Pakistani stock market.

As there will be time series data in same order containing stock prices of equity market of Pakistan and eight developed countries, So Co-integration requires checking of stationary and non-stationary of data at level and trend, for this purpose we will use unit root test by applying augmented Dickey Fuller test and PhillipsPerron test.

The Augmented Dickey-Fuller test examines the presence of unit root in an autoregressive model. A simple AR(1) model is $y t=\rho y t-1+\mu t$ where $y t$ is the variable of interest, $t$ is the time index, $\rho$ is the coefficient and $\mu$ tis the error term. The regression modal can be written as $\Delta y \mathrm{t}=(\rho-1) \mathrm{yt}-1+\mu \mathrm{t}=\delta \mathrm{yt}-1+\mu \mathrm{t}$ where $\Delta$ is the first difference operator. This model can be estimated and testing for a unit root is equating to testing $\delta=0$.TheDickeyFuller tests assume that the error term are statistically independent and have a constant variance which is rather strict assumption so an alternative test, the Phillip-Peron test is also used to test the stationarity of data. It may be noted that Phillip-Peron test allows the error term to be weakly dependent and heterogeneously distributed.

Application of Johansen and Juselius approach require selection of proper lag length. This approach will check the stationarity of data. For this purpose Akaike Information criterion (AIC) and Schwarz information Criterion (SIC) is used from 1 to 12 months. The appropriate lag length is considered where SIC is found minimum.

Co-integration requires that all the time series should be integrated of same order and assumes that even if two time series are individually non-stationary, a linear combination of two might be stationary. Relationship between two or more variables is analyzed through co- integration. Co-integration examine the co-movement between two series or more series, it does not covers the cause and effect association. Its basis are realistic proof. It is necessary that there might or might not be any economic rational for the proof of this association. The method itself does not discourse any cause and effect relationship. Johansen and Juselius recommend two likelihood ratio tests for the purpose determining the number of co-integrated vectors. Trace statistic is the base of first test and this test exam the null hypothesis of $r$ co-integration vectors or routes against the alternative of $r$ or more co-integration vectors. The equation of this statistic is given by $\lambda$ trace $=-T \sum \ln (1-\lambda \mathrm{i})$

Maximal Eigen value test is the second test which calculates the null hypothesis that there are most $r$ co-integration vectors against the alternative of $r+1$ co-integration vectors. The maximum Eigen value statistic is expressed by $\lambda \max =-\mathrm{T} \ln (1-\lambda \mathrm{r}+1)$ observations.

Where $\lambda r+1 \ldots \lambda n$ are the $n-r$ smallest squared canonical correlations and $T$ the number of 


\section{Empirical Results}

\subsubsection{TABLE 1}

DESCRIPTIVE STATISTICS

\begin{tabular}{|l|c|c|c|c|c|c|c|c|c|}
\hline & LAUS & LCAN & LFRA & LGER & LJAP & LNEI & LPAK & LUK & LUSA \\
\hline Mean & 8.4637 & 7.8749 & 8.2562 & 8.8138 & 9.3105 & 5.8477 & 9.4678 & 8.6390 & 8.6797 \\
\hline Median & 8.4563 & 7.8832 & 8.2266 & 8.8281 & 9.2314 & 5.8243 & 9.4093 & 8.6552 & 8.6901 \\
\hline Maximum & 8.8179 & 8.3912 & 8.6738 & 9.2041 & 9.7553 & 6.3060 & 10.300 & 8.8312 & 9.0164 \\
\hline Minimum & 8.1150 & 7.2282 & 7.9019 & 8.2587 & 8.9310 & 5.3798 & 8.5899 & 8.2506 & 8.1898 \\
\hline Std. Dev. & 0.1434 & 0.2636 & 0.1715 & 0.2066 & 0.2222 & 0.1985 & 0.3912 & 0.1367 & 0.1896 \\
\hline Skewness & 0.1767 & -0.1468 & 0.5903 & -0.2777 & 0.4261 & 0.2172 & 0.2464 & -0.8877 & -0.2580 \\
\hline Kurtosis & 3.0763 & 2.8771 & 3.0864 & 2.9207 & 1.8471 & 3.2037 & 2.7639 & 3.3679 & 2.4543 \\
\hline Jarque-Bera & 0.4577 & 0.3548 & 4.9060 & 1.1020 & 7.1958 & 0.8060 & 1.0452 & 11.508 & 1.9743 \\
\hline Probability & 0.7954 & 0.8374 & 0.0860 & 0.5763 & 0.0270 & 0.6682 & 0.5929 & 0.0031 & 0.3726 \\
\hline Sum & 710.95 & 661.49 & 693.52 & 740.36 & 782.08 & 491.20 & 795.29 & 725.68 & 729.09 \\
\hline SumSq. Dev. & 1.7081 & 5.7673 & 2.4432 & 3.5458 & 4.1013 & 3.2714 & 12.708 & 1.5510 & 2.9839 \\
\hline Observations & 84 & 84 & 84 & 84 & 84 & 84 & 84 & 84 & 84 \\
\hline
\end{tabular}

\section{INTERPRETATION}

Results of table 1 shows that Descriptive statistics is applied on 9 stock markets for the period of July 2007 to June 2014. The results of descriptive statistics shows that average return of KSE-100 is 9.46 at a given risk level of (standard deviation) .39 which is highly return as compared to other developed markets during this period. Stock market of Japan is also revealing highly return near to 9.31 at a given level of standard deviation .22 while stock market of Netherlands is showing the lowest return from all the markets i.e. 5.84 at a given risk level of 0.19 . The results also indicates that KSE is the most risky market among all the stock markets with high level of return while AEX (Neither lands) is the less risky with lower rate of return.

\subsubsection{TABLE 2}

CORRELATION MATRIX

\begin{tabular}{|c|c|c|c|c|c|c|c|c|c|}
\hline & LAUS & LCAN & LFRA & LGER & LJAP & LNEI & LPAK & LUK & LUSA \\
\hline LAUS & 1 & & & & & & & & \\
\hline LCAN & 0.5500 & 1 & & & & & & & \\
\hline LFRA & 0.9571 & 0.3718 & 1 & & & & & & \\
\hline LGER & 0.7507 & 0.9445 & 0.6241 & 1 & & & & & \\
\hline LJAP & 0.9045 & 0.5609 & 0.8788 & 0.7347 & 1 & & & & \\
\hline LNEI & 0.9633 & 0.5304 & 0.9520 & 0.7347 & 0.8557 & 1 & & & \\
\hline LPAK & 0.5985 & 0.9443 & 0.4402 & 0.9304 & 0.6475 & 0.5704 & 1 & & \\
\hline LUK & 0.8063 & 0.9044 & 0.6702 & 0.9624 & 0.7278 & 0.8007 & 0.8740 & 1 & 1 \\
\hline LUSA & 0.8098 & 0.8863 & 0.7012 & 0.9554 & 0.8129 & 0.8078 & 0.9146 & 0.9467 & 1 \\
\hline
\end{tabular}

\section{INTERPRETATION}

Table 2 indicates the result of correlation analysis among stock markets returns. The result of correlation matrix explores that KSE 100 is weakly correlated with selected world stock markets. The highest correlation of KSE is with the Canada i.e. 0.94 and with the Germany i.e. 0.93 while the lowest correlation of KSE is with the Francei.e. 0.44. Correlation matrix is a weak measure to check the relationship of variables. For better picture of the analysis for measuring co-movement among the markets, we move towards the co integration approach for further analysis. 


\subsubsection{TABLE 3}

UNIT ROOT TEST

USING AUGMENTED DICKEY-FULLER (ADF) TEST

\begin{tabular}{|c|c|c|c|c|}
\hline $\begin{array}{c}\text { Variables } \\
\text { (Equity Markets) }\end{array}$ & Country & At Level & At First Difference & Remarks \\
\hline ASX & Australia & -3.395327 & -7.417972 & Stationary at First Difference \\
\hline TSX & Canada & -2.019494 & -7.569126 & Stationary at First Difference \\
\hline CAC-40 & France & -3.017959 & -7.689197 & Stationary at First Difference \\
\hline DAX & Germany & -2.842913 & -4.770863 & Stationary at First Difference \\
\hline NIKKEI-225 & Japan & -1.812010 & -7.758577 & Stationary at First Difference \\
\hline AEX & Netherlands & -3.015289 & -7.777720 & Stationary at First Difference \\
\hline KSE-100 & Pakistan & -1.709505 & -8.057716 & Stationary at First Difference \\
\hline FTSE-100 & U.K & -2.277078 & -8.878163 & Stationary at First Difference \\
\hline NYSE & U.S.A & -1.760635 & -7.683388 & Stationary at First Difference \\
\hline
\end{tabular}

\section{INTERPRETATION}

The result of unit root test in Table 3 by applying the ADF approach showing the non-stationarity of all the variables at level but at a first difference, the series became stationary at significant level. Lag lengths for ADF test was selected by Schwarz information criterion (SIC).

\subsubsection{TABLE 4}

\section{UNIT ROOT TEST \\ USING PHILLIPS-PERRON (PP) TEST}

\begin{tabular}{|c|c|c|c|c|}
\hline $\begin{array}{c}\text { Variables } \\
\text { (Equity } \\
\text { Market) }\end{array}$ & Country & At Level & $\begin{array}{c}\text { At First } \\
\text { Difference }\end{array}$ & Remarks \\
\hline ASX-100 & Australia & -1.985534 & -7.329532 & Stationary at First Difference \\
\hline TSX & Canada & -2.164987 & -7.535687 & Stationary at First Difference \\
\hline CAC-40 & France & -1.889464 & -7.613585 & Stationary at First Difference \\
\hline DAX & Germany & -2.102992 & -7.753066 & Stationary at First Difference \\
\hline NIKKEI-225 & Japan & -1.881497 & -7.764683 & Stationary at First Difference \\
\hline AEX & Netherlands & -2.061515 & -7.779560 & Stationary at First Difference \\
\hline KSE-100 & Pakistan & -1.743275 & -8.056752 & Stationary at First Difference \\
\hline FTSE-100 & U.K & -2.277078 & -8.875990 & Stationary at First Difference \\
\hline NYSE & U.S.A & -1.813764 & -7.685366 & Stationary at First Difference \\
\hline
\end{tabular}

\section{INTERPRETATION}

By applying the PP test at level and at first difference the result of unit root test in Table 4 shows that all the variables are non-stationary at level but at first difference, all series become stationary at 5\% significant level. It is clear from the application of unit root test using ADF and PP that monthly stock prices of nine countries are non-stationary at level and stationary at first difference using 5\% level of significance. The outcomes of Unit root test are providing base for the application of Co-integration on this time series data. Lag lengths for PP test was selected by Schwarz information criterion (SIC). 


\subsubsection{TABLE 7}

\section{JOHNSONS JULESIS CO-INTEGRATION TEST}

(MAXIMUM EIGEN STATISTICS)

\begin{tabular}{|c|c|c|c|c|}
\hline $\begin{array}{c}\text { Hypothesized } \\
\text { No of CEs }\end{array}$ & Eigen Value & $\begin{array}{c}\text { Max-Eigen } \\
\text { Statistics }\end{array}$ & $\begin{array}{c}\text { 0.05 } \\
\text { Critical Value }\end{array}$ & Probability** $^{*}$ \\
\hline $\mathrm{r}=0$ & $\mathrm{r}=1$ & 55.31322 & 54.96577 & 0.0461 \\
\hline $\mathrm{r}=1$ & $\mathrm{r}=2$ & 50.31898 & 48.87720 & 0.0350 \\
\hline $\mathrm{r}=2$ & $\mathrm{r}=3$ & 34.84122 & 42.77219 & 0.2853 \\
\hline $\mathrm{r}=3$ & $\mathrm{r}=4$ & 21.67426 & 36.63019 & 0.7982 \\
\hline $\mathrm{r}=4$ & $\mathrm{r}=5$ & 17.74576 & 30.43961 & 0.7184 \\
\hline $\mathrm{r}=5$ & $\mathrm{r}=6$ & 11.55860 & 24.15921 & 0.8153 \\
\hline $\mathrm{r}=6$ & $\mathrm{r}=7$ & 7.609402 & 17.79730 & 0.7484 \\
\hline $\mathrm{r}=7$ & $\mathrm{r}=8$ & 4.890272 & 11.22480 & 0.4929 \\
\hline $\mathrm{r}=8$ & $\mathrm{r}=9$ & 0.574307 & 4.129906 & 0.5104 \\
\hline
\end{tabular}

Max-eigenvalue test indicates 2 co integrating eqn (s) at the 0.05 level

* denotes rejection of the hypothesis at the 0.05 level

**MacKinnon-Haug-Michelis (1999) p-values

\section{INTERPRETATION}

Estimated results of Multivariate co integration based on Johansen (1990) co integration test (Maximum Eigen statistics) are shown in Table 7. Maximum Eigen statistics test confirming that there are 2 co integration equations at 0.05 level. It simply means that there are two markets out of the nine markets which are co moving.

\subsubsection{TABLE 8}

BI-VARIATE ANALYSIS

JOHNSONS JULESIS CO-INTEGRATION TEST (TRACE STATISTICS)

\begin{tabular}{|c|c|c|c|c|c|}
\hline Variables & Hypothesis & $\begin{array}{c}\text { Trace } \\
\text { Statistics }\end{array}$ & $\begin{array}{l}0.05 \text { Critical } \\
\text { Value }\end{array}$ & Probability & Remarks \\
\hline \multirow{2}{*}{$\begin{array}{l}\text { KSE } 100 \\
\text { and NYSE }\end{array}$} & $\mathrm{r}=0$ & 4.338661 & 12.32090 & 0.6619 & \multirow{2}{*}{ No Co integration Exist } \\
\hline & $r=<$ & 0.908075 & 4.129906 & 0.3941 & \\
\hline \multirow{2}{*}{$\begin{array}{l}\text { KSE } 100 \\
\text { and TSX }\end{array}$} & $\mathrm{r}=0$ & 10.84883 & 12.32090 & 0.0871 & \multirow{2}{*}{ No Co integration Exist } \\
\hline & $\mathrm{r}=<$ & 0.791411 & 4.129906 & 0.4303 & \\
\hline \multirow{2}{*}{$\begin{array}{l}\text { KSE } 100 \\
\text { and CAC }\end{array}$} & $\mathrm{r}=0$ & 4.405610 & 12.32090 & 0.6522 & \multirow{2}{*}{ No Co integration Exist } \\
\hline & $\mathrm{r}=<$ & 1.148626 & 4.129906 & 0.3307 & \\
\hline \multirow{2}{*}{$\begin{array}{l}\text { KSE } 100 \\
\text { and DAX }\end{array}$} & $\mathrm{r}=0$ & 3.567214 & 12.32090 & 0.7723 & \multirow{2}{*}{ No Co integration Exist } \\
\hline & $\mathrm{r}=<$ & 0.643571 & 4.129906 & 0.4829 & \\
\hline \multirow{2}{*}{$\begin{array}{l}\text { KSE } 100 \\
\text { and Nikkei }\end{array}$} & $\mathrm{r}=0$ & 5.230018 & 12.32090 & 0.5357 & \multirow{2}{*}{ No Co integration Exist } \\
\hline & $r=<$ & 1.025091 & 4.129906 & 0.3615 & \\
\hline \multirow{2}{*}{$\begin{array}{l}\text { KSE } 100 \\
\text { and ASX }\end{array}$} & $\mathrm{r}=0$ & 2.823627 & 12.32090 & 0.8692 & \multirow{2}{*}{ No Co integration Exist } \\
\hline & $\mathrm{r}=<$ & 0.393505 & 4.129906 & 0.5937 & \\
\hline \multirow{2}{*}{$\begin{array}{l}\text { KSE } 100 \\
\text { and FTSE }\end{array}$} & $\mathrm{r}=0$ & 1.547179 & 12.32090 & 0.9785 & \multirow{2}{*}{ No Co integration Exist } \\
\hline & $\mathrm{r}=<$ & 0.054759 & 4.129906 & 0.8479 & \\
\hline \multirow{2}{*}{$\begin{array}{l}\text { KSE } 100 \\
\text { and AEX }\end{array}$} & $\mathrm{r}=0$ & 8.427773 & 12.32090 & 0.2054 & \multirow{2}{*}{ No Co integration Exist } \\
\hline & $r=<$ & 1.329054 & 4.129906 & 0.2911 & \\
\hline
\end{tabular}

\section{INTERPRETATION}

The Table 8 reveals the result of the pair wise co integration test for the whole selected time period. It is instituted that KSE is not co integrated with any stock markets as in the table value of probability is insignificant in each pair wise relationship of stock markets. Hence the fund managers of these countries may get the benefits of portfolio diversification by investing in KSE. The results reveal that KSE-100 has no relationships to the markets of developed countries at 0.05 level, consequently, it provides the chance of portfolio diversification benefits to the investors of these developed countries. Accordingly, the financiers of all these non co-integrated countries can obtain the maximum advantages by making their investment in the stock market of Pakistan. The results of the study also confirms the theory of Portfolio Investment given by Markowitz 1952.

\section{CONCLUSIONS}

Internationalization increases the integration of economies and stock markets. Stock market co integration effects 
risk and return and the investment decisions. According to Portfolio diversification model (Markowitz 1952), Co movement of stock markets limits the benefits of portfolio diversification for foreign investors. Investors can minimize risk and maximize the return by diversification. Co integration limits the opportunities of diversification and discourages the foreign portfolio investment. Investors are searching such markets of the world having diversification opportunities with maximum return at minimum risk level.

The findings of this study concludes that KSE-100 has no co movement with the equity markets of selected developed countries during the taken time period extended from July 2007 to June 2014. No co movement provides an opportunity of diversification to the investors of Pakistan and the world. Descriptive statistics results shows that KSE is providing higher monthly returns i.e. 9.46 at 0.391 risk level as compared to all other selected developed equity markets. Results of correlation showing association among the stock markets. Unit root test using ADF and PP test on the monthly data to verify the stationary and non-stationary of the data. The results of Unit root test has verified that the data has non stationery trend at level and stationary trend at first difference using 5\% significant level. Lag value is determined by the VAR test for the co integration. VAR test results revealing that one lag value is affecting the today value by using Schwarz information criterion and one lag value has been used in co integration test. The results of multivariate co integration using trace statistics and maximum Eigen value showed that there are two co integration equations by using Schwarz information criteria (SIC). Two markets among the total markets have co integration. Co movement of KSE with all these markets have been examined individually by applying Bi-variate co integration. The results of bi-variate co integration using trace statistics and 5\% probability level reveals that KSE has no co movement with any equity market of the selected developed markets. All these results points out that KSE-100 has no relationship with the selected developed markets. The analysis of this study reveals that KSE is attracting the local and foreign investors and fund managers to get the diversification benefits by portfolio investment because there is no association between KSE and equity markets of developed countries.

No co movement of stock markets extends the opportunities of diversification benefits. Investors are searching such markets which have greater diversification benefits because diversification minimizes the risk element. These results confirms that the individual and institutional investors can get the benefits of diversification by investing in equity market of Pakistan. No co integration will attract the foreign investors to invest in Pakistan equity market. No co movement will increase the Foreign Direct Investment and Foreign Portfolio investment in Pakistan which is much helpful for the development of economy of Pakistan through investing in energy, communication and industrial sector, strengthening the Pakistani rupee, reducing the dependency on foreign debts, reducing the imports of capital items and making the budget favorable. This will also help to resolve the problem of deficiency of foreign exchange reserve faced by the economy of Pakistan. Economy of Pakistan will boost up through foreign investment which is required for the development projects. The results of this study are also equal beneficial for Pakistani investors and policy makers. Pakistani investors and fund managers can also receive the diversification benefits from the selected stock markets of developed countries.

\section{FUTURE RESEARCH DIRECTIONS}

This study explores the new dimensions for the future researchers. This study has taken eight major developed countries that have portfolio investment in Pakistan. Future researchers can take the major developed as well as developing economies for the same analysis. Study can be made on the co-movement of Pakistan stock market with the emerging economies of the South Asia region which are trading partner of Pakistan. Analyses can be made by using daily and weekly time series data. Effect of macro-economic variables can be included in this study. This study provides the base for the study of foreign portfolio investment in developing countries and impacts of co integration on FPI. Co movement of KSE can be examined with such developed countries having Foreign Direct Investment in Pakistan for the same period. Co movement of KSE with the equity markets of developed countries taking the period of contagion can be analyzed by new researchers. Future researchers can also explore the factors of economic integration of Pakistan Stock Market (KSE-100) with stock markets of developed countries.

\section{END REFERENCES}

Ali, S., Butt, B. Z., \& Rehman, K. (2011). Co movement between emerging and developed stock markets: an investigation through co integration analysis. World Applied Sciences Journal, 12(4), 395-403.

Bekaert, G., \& Harvey, C. R. (1997). Emerging equity market volatility. Journal of Financial economics, 43(1), 29-77.

Bhunia, A., \& Das, A. (2012). Financial Market Integration: Empirical Evidence from India and Select South Asian Countries. Afro Asian Journal of Social Sciences, 3(3.1).

Blackburn, D. W., \& Chidambaran, N. K. (2011). Is World Stock Market Co-Movement Changing? Available at SSRN 2024770. 
Claus, E., \& Lucey, B. M. (2012). Equity market integration in the Asia Pacific region: evidence from discount factors. Research in International Business and Finance, 26(2), 137-163.

Chen, J. (2011). What explains the cross-country differences in stock return co movement? A return decomposition analysis. Working paper, The Ohio State University.

Chow, G. C., Huang, S., \& Niu, L. (2013). Econometric Analysis of Stock Price Co-movement in the Economic Integration of East Asia.

Da Fonseca, J. S. (2013). The International Integration of the Eastern Europe and two Middle East Stock Markets (No. 2013-01). GEMF-Faculdade de Economia, Universidade de Coimbra.

Darrat, A. F., Colthup, G., Li, B., \&Zhong, M. (2012). Market Interdependence In The Pacific Basin Region: Internal Drives And External Influences. Journal of Applied Business Research (JABR), 28(4), 619-632.

Dickey, D. A., and Fuller, W. A. (1981). Likelihood Ratio Statistics for Autoregressive Time Series with Unit Root. Econometrica, 49, 1057-1072.

Esqueda, O. A., Assefa, T. A., \& Mollick, A. V. (2012). Financial globalization and stock market risk. Journal of International Financial Markets, Institutions and Money, 22(1), 87-102.

Granger, C. W. J. (1969). Investigating causal relations by econometric models and cross-spectral methods. Econometrica: Journal of the Econometric Society, 424-438.

Hoque, H. A. A. B. (2007). Co-movement of Bangladesh stock market with other markets: Co integration and error correction approach. Managerial Finance, 33(10), 810-820.

Horvath, R., \&Petrovski, D. (2013). International stock market integration: Central and South Eastern Europe compared.Economic Systems, 37(1), 81-91.

Hussain, A., \& Mohammad, S.D. (2011). The Dynamic Linkages of Pakistani and Global Stock Markets: Evidence from Karachi Stock Exchange. Pak. J. Commerce. Soc. Sci., 2011 Vol. 5 (2), 233-242.

Johansen, S., \& Juselius, K. (1990). Maximum likelihood estimation and inference on cointegration-with applications to the demand for money. Oxford Bulletin of Economics and statistics, 52(2), 169-210.

Kim, H. (2010). Dynamic causal linkages between the US stock market and the stock markets of the East Asian economies.Royal Institute of Technology, CESIS-Centre of Excellence for Science and Innovation Studies. (No. 236).

Markowitz, H. (1952). Portfolio selection*. The journal of finance, 7(1), 77-91.

Morales, L., \& Andreosso-O'Callaghan, B. (2012). The current global financial crisis: Do Asian stock markets show contagion or interdependence effects? Journal of Asian Economics, 23(6), 616-626.

Petrov, P. (2011). Cointegration in equity markets: a comparison between South African and major developed and emerging markets (Doctoral dissertation, Rhodes University).

Shah, S. M. A., Husnain, M., \& Ali, A. (2012). Is Pakistani Equity Market Integrated to the Equity Markets of Group of Eight (G8) Countries? An Empirical Analysis of Karachi Stock Exchange. Romanian Economic Journal, 15(45).

Subhani, M. I., Hasan, D., Akif, S., Mehar, D., \& Osman, M. (2011). Are the major South Asian equity markets co-integrated? International Journal of Humanities and Social Science, 12(1), 117-121.

Singh, G., \& Singh, P. (2011). Chinese and Indian Stock Market Linkages with Developed Stock Markets. Asian Journal of Finance \& Accounting, 2(2). 
The IISTE is a pioneer in the Open-Access hosting service and academic event management. The aim of the firm is Accelerating Global Knowledge Sharing.

More information about the firm can be found on the homepage:

http://www.iiste.org

\section{CALL FOR JOURNAL PAPERS}

There are more than 30 peer-reviewed academic journals hosted under the hosting platform.

Prospective authors of journals can find the submission instruction on the following page: http://www.iiste.org/journals/ All the journals articles are available online to the readers all over the world without financial, legal, or technical barriers other than those inseparable from gaining access to the internet itself. Paper version of the journals is also available upon request of readers and authors.

\section{MORE RESOURCES}

Book publication information: http://www.iiste.org/book/

\section{IISTE Knowledge Sharing Partners}

EBSCO, Index Copernicus, Ulrich's Periodicals Directory, JournalTOCS, PKP Open Archives Harvester, Bielefeld Academic Search Engine, Elektronische Zeitschriftenbibliothek EZB, Open J-Gate, OCLC WorldCat, Universe Digtial Library, NewJour, Google Scholar

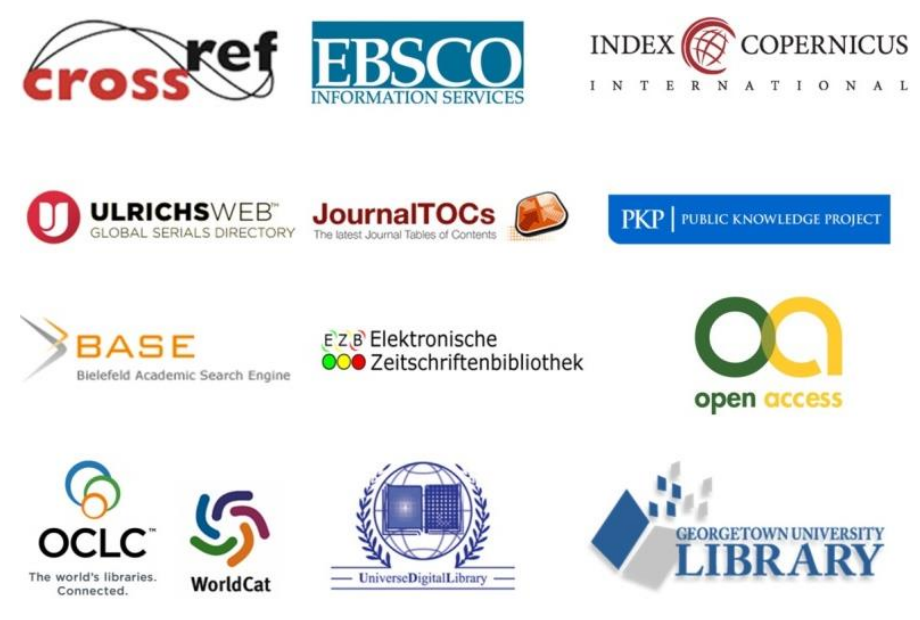

